Marquette University

e-Publications@Marquette

Marketing Faculty Research and Publications

Business Administration, College of

$1-1-2011$

\title{
An Empirical Note on Regionalization and Globalization
}

Syed H. Akhter

Marquette University, syed.akhter@marquette.edu

Colleen Beno

Marquette University, colleen.beno@marquette.edu

Accepted version. Multinational Business Review, Vol. 19, No. 1, (2011), pp. 26-35. DOI. This article is (C) Emerald Group Publishing and permission has been granted for this version to appear here ePublications@Marquette.Emerald does not grant permission for this article to be further copied/ distributed or hosted elsewhere without the express permission from Emerald Group Publishing Limited. 


\title{
An empirical note on regionalization and globalization
}

\author{
Syed H. Akhter \\ Marketing Department, Marquette University \\ Milwaukee, WI \\ Colleen Beno \\ Marketing Department, Marquette University \\ Milwaukee, WI
}

\begin{abstract}
:
Purpose - Is it regionalization or globalization that more accurately depicts the state of the global economy? Exports and foreign direct investments (FDI) data are analyzed with the aim of answering the question and determining how intra- and inter-regional integration has changed over time.

Design/methodology/approach - To address the research questions, this paper covers the following. First, it takes a longitudinal perspective in examining the changes taking place in exports and FDI at the regional level. Second, it draws strategic business and marketing implications of this development.
\end{abstract}

Findings - The results show a trend toward regionalization in the Quad (North America, Western Europe, Asia, and Latin America), especially with respect to exports data.

Originality/value - Findings, strategic implications, and directions for future research are presented.

Keywords: Globalization, Regional development, Exports, International investments, Direct investment

Paper type: Research paper 
NOT THE PUBLISHED VERSION; this is the author's final, peer-reviewed manuscript. The published version may be accessed by following the link in the citation at the bottom of the page.

\section{Introduction}

The rapid expansion of international business is the result of trade and investment enhancing policies of governments, developments in telecommunication and transportation technologies, and, more importantly, market expansion strategies of firms from both developed and developing economies. The growth in international trade and foreign direct investments (FDI) has changed the structure of cross-border value-creating activities ([7] Lévy, 1995) and reconfigured the locations of production- and marketing- specific activities and advantages. Developing economies, such as India and China, are not only producing low-value and standardized products, but are also contributing to the development of high-value-added products through investments in research and development. Multinationals, as entities that both create and respond to change, have integrated business activities across national borders to satisfy needs and wants of consumers and achieve a competitive edge in the marketplace. The term most commonly used to characterize these developments is globalization.

Although globalization has been defined differently, the term has come to mean worldwide participation in economic exchange activities ([6] Kim and Shin, 2002) and the increasing internationalization of production, distribution, and marketing of goods and services ([4] Harris, 1993). [14] Peng (2009, p. 11) defines globalization as "the close integration of countries and peoples of the world," and [21] Rundh (2007, p. 181) views it as "the shift toward a more integrated and interdependent world economy." In such marketoriented and integrationist views, the underlying theme is that globalization has expanded the scope of the market and created a worldwide market for goods and services. In this globalized construction, businesses are often perceived as indifferent to space, reaching out to where the markets are and where they can make a profit. In essence, it is argued that the pursuit of market opportunities and profit has taken them to the four corners of the flat world. Examples of Coke and Nike selling their products worldwide are readily given to support the contention of the global scope of today's markets.

The above scenario of the global economy is quite appealing and has found many adherents both in academia and the business community. Although this new picture is framed as reflective of what is

Multinational Business Review, Vol 19, No. 1 (2011): pg. 26-35. DOI. This article is @ Emerald and permission has been granted for this version to appear in e-Publications@Marquette. Emerald does not grant permission for this article to be further copied/distributed or hosted elsewhere without the express permission from Emerald. 
happening in today's world, it is also coming under greater scrutiny. [15] Rugman (2000) and others are hypothesizing that the reality in today's global economy is a growing trend towards regionalization, a clustering of markets within different regions. The regional hypothesis is based on the contention that exports and FDI, far from becoming global, are actually assuming a regional focus. It is this contention that gives rise to the two substantive questions addressed in this paper: first, whether it is regionalization and not globalization that is shaping the global economy; and second, whether international trade and investments are playing out their roles of achieving greater regional integration in North America, Western Europe, Asia, and Latin America.

To address the research questions, this paper covers the following. First, it takes a longitudinal perspective in examining the changes taking place in exports and FDI at the regional level. Second, it draws strategic business and marketing implications of this development. To achieve the above goals, the paper is divided into three sections. In the first section, the concept of regionalization is reviewed. In the second, issues related to sampling, data, and analysis are discussed and findings are presented. In the third, strategic implications are covered and questions for future research are recommended.

\section{Regionalization}

The reduction in trade and investment barriers has facilitated the flow of products and capital between nations. Furthermore, technological developments in transportation and communications have significantly reduced the cost of conducting international business and encouraged firms to expand their operations internationally in search of resources, markets, and efficiencies. This growth in international business has not only integrated the global economy, but also stimulated the growth of economic regionalization ([5] Hurrell, 1995). The intensification of intra- regional trade has been the outcome of regional comparative advantages that flow from economic integration, political commitment, and market proximity ([8] Macdissi, 2004). In addition, the growth in regional trade has been fueled by the willingness of governments to protect local economic interests in response to the pervasive and relentless pressure from foreign multinationals.

Multinational Business Review, Vol 19, No. 1 (2011): pg. 26-35. DOI. This article is (C) Emerald and permission has been granted for this version to appear in e-Publications@Marquette. Emerald does not grant permission for this article to be further copied/distributed or hosted elsewhere without the express permission from Emerald. 
After taking a back seat to the GATT's multilateral initiatives to increase global trade and investment, regional trade has once again emerged as an appealing option to shape and improve regional competitive positions. In recent years, there has been an undeniable resurgence of regionalism ([13] Pearce and Tavares, 2000). The reduction in tariff and non-tariff barriers helped facilitate the process of trade liberalization and improved the competitiveness of regional blocs through greater economies of scale ([1] Bhalla and Bhalla, 1997). Furthermore, the opening of local markets to goods and services from non-regional economies in regionally integrated markets has further improved the competitive positions of regional firms and laid the groundwork for their growth.

Business expansion into regional markets is the outcome of decisions taken by firms to enter a country market to consolidate their competitive positions. Geographical and cultural proximity, combined with growing market attractiveness, have encouraged regional growth of business. Firms have expanded and increased their level of involvement in their home countries and adjoining countries ([18] Rugman and Oh, 2008). Regional expansions act as a catalyst for further growth and expansion, and improvements in market potential further motivate firms to not only market products, but also to manufacture them regionally. China and India serve as good examples of how the increasing attractiveness of their markets has motivated firms in the region to enter these two economies to produce and sell.

Regional integration of markets gained momentum in Western Europe and North America soon after the Second World War and then moved on to Asia and Latin America. As countries began to form economic blocs, it was becoming obvious that economic regionalization, and not globalization, accurately reflected the state of the global economy ([3] Gittelman, 1997). Three economic blocs North America, Western Europe, and Japan with a few more Asian economies - became popular in the 1980s with the publication of Triad Power by [12] Ohmae (1985). The term "Triad" almost became synonymous with regionalization and was soon absorbed into the business lexicon, suggesting the presence of regional markets that provided opportunities for economies of scale and scope. While regional integration in the Triad remains strong, recent growth in South America presents a case for extending the geographic scope of the Triad to the developing economies of South America. This paper

Multinational Business Review, Vol 19, No. 1 (2011): pg. 26-35. DOI. This article is @ Emerald and permission has been granted for this version to appear in e-Publications@Marquette. Emerald does not grant permission for this article to be further copied/distributed or hosted elsewhere without the express permission from Emerald. 
includes this region in the analysis, making it a part of the Quad (North America, Western Europe, Asia, and Latin America).

\section{Method}

\section{Regional integration and the Quad}

Intra-regional exports (exports from an economy to economies within the region) and inter-regional exports (exports from an economy to economies outside the region) were analyzed to determine changes in the degree of regionalization. A similar procedure was followed for FDI. The use of both exports and FDI data adds to the existing literature, which, with some exceptions, has mostly focused on analyzing exports to measure growth in regionalization. Although the emphasis on exports limited the scope of analysis, the approach was considered appropriate because exporting is common to every economy and data on exporting are readily available. In recent years, however, FDI has grown significantly, and some of the major developing economies are now both a source and destination of FDI. Furthermore, in recent years, FDI has assumed an increasingly important role "in shaping international economic relations" ([3] Gittelman, 1997, p. 3) and impacted the international integration of value chain activities. In view of these developments, this study includes both exports and FDI data to determine the changes in the nature and degree of regionalization.

A total of 36 economies for exports were selected from the Quad. In North America, the three economies were the USA, Canada, and Mexico. In Western Europe, the 15 economies were Austria, Belgium, Denmark, Finland, France, Germany, Greece, Ireland, Italy, Luxembourg, The Netherlands, Norway, Portugal, Spain, and the UK. In Asia, the 13 economies were Australia, China, Hong Kong, India, Indonesia, Japan, South Korea, Malaysia, New Zealand, Philippines, Singapore, Taiwan, and Thailand. In Latin America, the five economies were Argentina, Brazil, Chile, Paraguay, and Uruguay. In the case of FDI, one more economy, Venezuela was added. These economies in the Quad represent over 80 percent of the world gross domestic product and 65 percent of the world population. 
NOT THE PUBLISHED VERSION; this is the author's final, peer-reviewed manuscript. The published version may be accessed by following the link in the citation at the bottom of the page.

\section{Exports and the Quad}

Michalak and Gibb (1997), in its analysis of 1991 trade data, found that intra-regional trade accounted for 38 percent of all the world's merchandise imports and exports, whereas inter-regional trade represented just 10 percent. Later, Rugman and Hodgetts (2001), based on Rugman (2000), examined trade data in the Triad in 1997 and found the prevalence of regionalization in exports, with intraNAFTA exports accounting for 49.1 percent, intra-Asia for 53.1 percent, and intra-EU for 60.6 percent. This prompted the authors to note that the core triad members do not rely on each other for most of their exports or imports, but on other members within their own triad. This paper's goal is to extend this stream of research and provide a comparative picture of changes in regionalization over time. Exports are covered first, and then FDI. For exports, the four periods covered in this study are 1970,1980, 1994, and 2006. The data for exports came from different editions of the Direction of Trade Statistics Yearbook, International Monetary Fund (IMF), Washington, DC.

In North America, the trend towards increasing regionalization is evident. Although intra-regional exports, as a percentage of total exports, decreased from 36 percent in 1970 to 34 percent in 1980, it increased to 49 percent in 1994, and then to 54 percent 2006. Data on inter-regional exports were mixed. North America's exports to Western Europe declined significantly from 26 percent in 1970 to 14 percent in 2006, but increased marginally to Asia, from 17 percent in 1970 to 18 percent in 2006. Exports from North America to Latin America remain at a very low level, declining from 3 percent in 1970 to 2 percent in 2006 (see Table I [Figure omitted. See Article Image.] for data on all years).

In Western Europe, intra-regional trade increased from 51 percent in 1970 to 60 percent in 1980, remained at 60 percent in 1994, and decreased to 59 percent in 2006. Western Europe's exports to North America increased from 10 percent in 1970 to 18 percent in 2006; and to Asia from 6 percent in 1970 to 8 percent in 2006. Exports to Latin America did not change, staying at 1 percent.

In Asia, there is an increasing trend toward regionalization. Although intra-regional trade stayed at 34 percent both in 1970 and 1980, it increased to 48 percent in 1994 and then to 52 percent in

Multinational Business Review, Vol 19, No. 1 (2011): pg. 26-35. DOI. This article is @ Emerald and permission has been granted for this version to appear in e-Publications@Marquette. Emerald does not grant permission for this article to be further copied/distributed or hosted elsewhere without the express permission from Emerald. 
2006. Inter-regional exports showed mixed results. Exports from Asia to North America declined from 29 percent in 1970 to 20 percent in 2006; but to Western Europe increased from 11 percent in 1970 to 14 percent in 2006. Latin America accounted for only 1 percent of exports in both 1970 and 2006.

In Latin America, there is also the general trend toward increasing regionalization. In 1970, intra-regional trade was only 11 percent, but increased to 17 percent in 1980 and then to 20 percent in 1994, and then declined to 15 percent in 2006. Inter-regional trade, however, showed mixed results. Exports to North America increased from 19 percent in 1970 to 21 percent in 2006; and to Asia from 8 percent in 1970 to 18 percent in 2006. However, exports to Western Europe declined significantly from 48 percent in 1970 to 21 percent in 2006.

\section{FDI and the Quad}

In contrast to exporting, which has had a long history of data collection, FDI lacks in both data coverage and reliability. The IMF has noted the deficiency in data collection, which creates the problem of comparability. This lack of comparability of data across countries, arising due to differences in the definition of FDI, data collection procedure, and corporate accounting practices across countries, raises a question about the validity of drawing inferences from crosssectional data and generalizing from findings. However, while there remain some data-related problems, there have also been significant improvements in the data collection procedures with emphasis on standardization and consistency, which have improved the reliability of FDI data. FDI data, published by United Nations, OECD, and IMF, are now regularly used by international business scholars.

\section{[Table 1]}

FDI have been growing consistently over the years, reaching $\$ 1.8$ trillion in 2007 . There have been significant changes in both the origin and destination of FDI in recent years. Although the developed economies remain the leading source of FDI, the role of developing economies has been increasing. From a negligible position in the

Multinational Business Review, Vol 19, No. 1 (2011): pg. 26-35. DOI. This article is @ Emerald and permission has been granted for this version to appear in e-Publications@Marquette. Emerald does not grant permission for this article to be further copied/distributed or hosted elsewhere without the express permission from Emerald. 
1980s, these economies have been adding a significant amount to the total outflows of FDI every year. In 2005, for example, they contributed close to $\$ 133$ billion, which amounted to 17 percent of the total FDI outflows (United Nations, 2006). In 2007, outflows of FDI from developing economies increased to $\$ 253$ billion. Not only have outflows from developing economies increased, but inflows of FDI into the developing economies have also seen a significant increase. In 2007 , the inflow of FDI into developing economies was close to $\$ 500$ billion (United Nations, 2008).

Among the developing economies, Brazil, India, and China have recently begun to play a significant role as both the recipient and source of FDI. These and other developing economies have internationalized their economies and are now investing not only in developed economies but also in other developing economies. Chinese total outflow of FDI increased from $\$ 1.3$ billion during 1990-1992 to $\$ 10.3$ billion during 2002-2003. During this period, there was a significant directional shift in the destination of these FDI. While the percentage of investment in developed economies decreased from 69.44 percent in $1990-1992$ to 22.60 percent in 2002-2003, it increased from 16.61 to 56.60 percent in Asia (Buckley et al. , 2007). These recent changes show two major developments: the growing participation of developing economies in FDI and the directional change in the destination of FDI. Overall, the Quad is both an important source and destination of FDI.

The FDI inflows are reported for 37 economies in 1990, 1997, 2000, and 2004. The time periods in the analysis of FDI are different from exports because FDI gained momentum in the 1990s.

Furthermore, while developing economies have always been involved in exporting products, they became a source of FDI much later. The 37 economies included in the analysis are grouped into four regions, representing the Quad: North America, Western Europe, Asia, and Latin America. Findings are based on data published by organizations such as OECD, IMF, and United Nations. In the section below, the regional and inter-regional flow of FDI originating from the Quad are presented. It should be noted that published data have a large number of missing values. In the analysis, these were not substituted with another value derived from a data substitution method, but treated as missing values (Table II [Figure omitted. See Article Image.]).

Multinational Business Review, Vol 19, No. 1 (2011): pg. 26-35. DOI. This article is @ Emerald and permission has been granted for this version to appear in e-Publications@Marquette. Emerald does not grant permission for this article to be further copied/distributed or hosted elsewhere without the express permission from Emerald. 
As indicated earlier, one of the shortcomings of published data is missing values for many economies. The region with the most missing values is Latin America. Considering that the secondary sources do not provide complete data, the findings presented below should be considered as estimates. However, they do provide a bird's eye view of the changes taking place in the direction of FDI. A summary of findings is presented next.

In North America, intra-regional FDI, as a percentage of FDI in all the four regions, increased from 26 percent in 1990 to 33 percent in 1997 and to 36 percent in 2000, but then declined to 27 percent in 2004. Inter-regional FDI showed great variations. FDI to Western Europe was 48 percent in 1990 and declined to 21 percent in 2004. FDI from North America to Asia increased from 20 percent in 1990 to 48 percent 2004. Latin America as a destination became less important, decreasing from 5 percent in 1990 to 3 percent in 2004.

\section{[Table II]}

In Western Europe, the trend is also towards increasing regionalization. Intra-regional FDI in 1990 was 59 percent, declining to 39 percent in 1997, increasing to 61 percent in 2000, and then further increasing to 72 percent in 2004. FDI from Western Europe to North America decreased from 32 percent in 1990 to 15 percent in 2004. FDI to Asia did not change much, decreasing slightly from 8 percent in 1990 to 7 percent in 2004. Latin America increased in importance, attracting 1 percent in 1990 and increasing to 5 percent in 2004 .

In Asia, the intra-regional FDI showed a trend toward regionalization, increasing from 39 percent in 1990 to 75 percent in 1997 and then declining to 63 percent in 2000 and remaining at 63 percent in 2004. FDI to North America saw a decline from 43 percent in 1990 to 22 percent in 2004. The importance of Western Europe did not change much. In 1990, the outflow to Western Europe was 18 percent and then declined to 15 percent in 2004. Latin America remained a minor destination for Asia's FDI.

In Latin America, there was significant volatility. Intra-regional FDI increased from 8 percent in 1990 to 72 percent in 1997, but 
declined to 30 percent in 2000 and then declined further to 6 percent in 2004. The outflow to North America saw a significant increase, from 27 percent in 1990 to 77 percent in 2004. FDI to Western Europe declined from 66 percent in 1990 to 15 percent in 2004. Asia played a marginal role in receiving FDI from Latin America.

\section{Conclusion and implications}

Findings from the study show that the global economy is moving forward on two parallel tracks. On one track, increasing trade and investments between nations is resulting in greater integration of the global economy, and, on the other track, increasing intra- regional trade and investments is bringing about greater regional integration. While both these developments characterize the global economy, it is regionalization that has taken the lead and best reflects the current trend. A deeper level of integration is occurring in the Quad (North America, Western Europe, Asia, and Latin America). As these regional markets grow in size, and as access to these markets allow firms the most effective and efficient use of resources, regional trade and investments can be expected to increase further.

The rising regional integration is partly the result of governmental actions taken to enhance the bargaining power of the region vis-à-vis other non-regional countries in multilateral negotiations (Mansfield and Reinhardt, 2003). The increase in bargaining power confers on them the advantage of selecting what they agree to and what they reject in negotiations. Governments are therefore creating market conditions through intra-regional policy coordination that promote trade and investments. These policies have reduced trade and investment barriers, giving firms within the bloc greater access to regional markets. Such access facilitates the development of region-based strategy, as examples of the automotive sector (Rugman and Collinson, 2004), cosmetics (Oh and Rugman, 2006), and retail sector (Rugman and Girod, 2003) demonstrate.

From a business perspective, regional integration will proceed smoothly as it provides a compromise between the two extremes of localization and globalization. Localization, for example, precludes firms from enjoying the benefits of scale, whereas globalization fails to effectively address the presence of heterogeneity (Pearce and Tavares, 2000). Furthermore, localization, by targeting specific needs of

Multinational Business Review, Vol 19, No. 1 (2011): pg. 26-35. DOI. This article is @ Emerald and permission has been granted for this version to appear in e-Publications@Marquette. Emerald does not grant permission for this article to be further copied/distributed or hosted elsewhere without the express permission from Emerald. 
consumers, reduces the size of the market and becomes appealing for a country-by-country approach to marketing, which increases production and marketing costs. Globalization, on the other hand, by targeting aggregated needs of consumers, increases the size of the market, but becomes less appealing to consumers. As a mid-level position between the two extremes, regional strategy allows firms to exploit resources more effectively and efficiently by creating geographically proximate market clusters.

Rugman (2000), Rugman and Hodgetts (2001) and Rugman (2001) have questioned the validity of viewing the world as one single market in light of the growing integration of business activities at regional levels followed by the implementation of regional strategies. The analysis of macro data in this study also supports their contention of growing regionalization, which is taking place in the Quad. This growing regionalization, as this paper demonstrates, provides the new backdrop for strategic business decisions.

Whereas globalization, with its focus on standardized products and marketing strategies for the global market, may have prevailed in the past, decisions that focus on regional differences and similarities currently seem more relevant and appropriate. This focus on a regional strategy will directly affect a number of business decisions, including:

- a greater focus on home region expansion, based on regional integration;

- the development of organizational structures that are regionappropriate; and

- a greater focus on local idiosyncrasies so as to modify the business plan as necessary (Rugman and Hodgetts, 2001, p. 341).

Home-region partnerships can prove extremely advantageous in creating market opportunities and consolidating market positions. Furthermore, such partnerships will help in the creation and transfer of knowledge and the development of region-focused marketing campaigns.

As the findings support the growing importance of regionalization, future research can explore three critical dimensions of this development. First, this paper examined aggregate export data to study the regionalization trend. Future research can focus on 
disaggregating the data to determine the changing composition of products (commodity vs differentiated products; low-value vs highvalue-added products) being traded regionally. This will provide further evidence of not only the degree, but also of the quality of regional integration.

Second, the recent entry of developing economies into the exclusive club of foreign direct investors has major implications for restructuring the global competitive environment. The highly publicized acquisitions of some of the global iconic brands - for example, Jaguar and Land Rover by Tata Motors of India and of IBM's ThinkPad by Lenovo - have received much attention lately. What has not received much attention, however, is how increasing FDI from developing economies is changing value chain activities regionally. As an example, Chinese investments in India provide interesting case studies for grounded theory development, especially with respect to internationalization of firms from developing economies.

Third, regional strategies find their place at the midpoint of the continuum of localization and standardization. This half-way point attempts to incorporate elements of both localization and standardization. The research question is, therefore, which elements of the marketing mix were adapted and which were standardized, as strategies moved to the midpoint from each direction. Of course, the antecedents of regional strategies that are internal to the firm and external to the environment will also need to be examined.

\section{References}

Bhalla, A.S. and Bhalla, P. (1997), Regional Blocs: Building Blocks or Stumbling Blocks?, St Martin's, New York, NY.

Buckley, P.J., Clegg, L.J., Cross, A.R., Liu, X., Voss, H. and Zheng, P. (2007), "The determinants of Chinese outward foreign direct investment", Journal of International Business Studies, Vol. 38 No. 4, pp. 499-518.

Gittelman, M. (1997), "Foreign direct investment in the Triad: a framework for understanding regionalization in the 1990s", The International Executive, Vol. 39 No. 1, pp. 67-81.

Harris, R.G. (1993), "Globalization, trade and income", Canadian Journal of Economics, Vol. 26 No. 4, pp. 755-76.

Hurrell, A. (1995), "Explaining the resurgence of regionalism in world politics", Review of International Studies, Vol. 21 No. 4, pp. 331-58.

Multinational Business Review, Vol 19, No. 1 (2011): pg. 26-35. DOI. This article is @ Emerald and permission has been granted for this version to appear in e-Publications@Marquette. Emerald does not grant permission for this article to be further copied/distributed or hosted elsewhere without the express permission from Emerald. 
NOT THE PUBLISHED VERSION; this is the author's final, peer-reviewed manuscript. The published version may be accessed by following the link in the citation at the bottom of the page.

Kim, S. and Shin, E.-H. (2002), "A longitudinal analysis of globalization and regionalization in international trade: a social network approach", Social Forces, Vol. 81 No. 2, pp. 445-68.

Le'vy, B. (1995), "Globalization and regionalization: toward the shaping of a tripolar world economy?", The International Executive, Vol. 37 No. 4, pp. 349-71.

Macdissi, C.M. (2004), "Regionalization and specialization: a theoretical contribution", Journal of American Academy of Business, Vol. 4 Nos $1 / 2$, pp. 471-5

Mansfield, E.D. and Reinhardt, E. (2003), "Multinational determinants of regionalism: the effects of GATT/WTO on the formation of preferential trading arrangements", International Organization, Vol. 57 No. 4, pp. 829- 62.

Michalak, W. and Gibb, R. (1997), "Trading blocs and multilateralism in the world economy", Annals of the Association of American Geographers, Vol. 87 No. 2, pp. 264-79.

Oh, C.H. and Rugman, A.M. (2006), "Regional sales of multinationals in the world cosmetics industry", European Management Journal, Vol. 24 Nos 2/3, pp. 163-73.

Ohmae, K. (1985), Triad Power, The Free Press, New York, NY.

Pearce, R. and Tavares, A.T. (2000), "Emerging trading blocs and their impact on the strategic evolution of multinationals", Managerial Finance, Vol. 26 No. 1, pp. 26-40.

Peng, M.W. (2009), Global Business, South-Western Cengage, Mason, OH. Rugman, A.M. (2000), The End of Globalization, Random House, London. Rugman, A.M. (2001), "The myth of global strategy", International Marketing Review, Vol. 18 No. 6, pp. 583-8.

Rugman, A.M. and Collinson, S. (2004), "The regional nature of the world's automotive sector", European Management Journal, Vol. 22 No. 5, pp. 471-82.

Rugman, A.M. and Girod, S. (2003), "Retail multinationals and globalization: the evidence is regional", European Management Journal, Vol. 21 No. 1 , pp. 24- 37.

Rugman, A.M. and Hodgetts, R. (2001), "The end of global strategy", European Management Journal, Vol. 19 No. 4, pp. 333-43.

Multinational Business Review, Vol 19, No. 1 (2011): pg. 26-35. DOI. This article is @ Emerald and permission has been granted for this version to appear in e-Publications@Marquette. Emerald does not grant permission for this article to be further copied/distributed or hosted elsewhere without the express permission from Emerald. 
NOT THE PUBLISHED VERSION; this is the author's final, peer-reviewed manuscript. The published version may be accessed by following the link in the citation at the bottom of the page.

Rugman, A.M. and Oh, C.H. (2008), "Friedman's follies: insights on the globalization/regionalization debate", Business and Politics, Vol. 10 No. 2, pp. 1-14.

Rundh, B. (2007), "International marketing behaviour amongst exporting firms", European Journal of Marketing, Vol. 41 Nos 1/2, pp. 181-98.

United Nations (2006), World Investment Report, United Nations, New York, NY.

United Nations (2008), World Investment Report, United Nations, New York, NY.

\section{About the authors}

Syed $\mathrm{H}$. Akhter is Professor of Marketing and Chairman of the Marketing Department at Marquette University. His research interests include globalization, consumer psychology, strategic marketing, and e-marketing. He has published in leading international business and marketing journals such as Journal of International Business Studies, International Marketing Review, European Journal of Marketing, International Trade Journal, Business Horizons, and Journal of Advertising. He has published two books, Global Marketing and Strategic Marketing and guest edited special issues of the Journal of Direct Marketing on international direct marketing and a special issue of the Journal of Interactive Marketing on international interactive marketing. Syed $\mathrm{H}$. Akhter is the corresponding author and can be contacted at: syed.akhter@marquette.edu Colleen Beno has an MBA from Marquette University.

Multinational Business Review, Vol 19, No. 1 (2011): pg. 26-35. DOI. This article is @ Emerald and permission has been granted for this version to appear in e-Publications@Marquette. Emerald does not grant permission for this article to be further copied/distributed or hosted elsewhere without the express permission from Emerald. 
NOT THE PUBLISHED VERSION; this is the author's final, peer-reviewed manuscript. The published version may be accessed by following the link in the citation at the bottom of the page.

Table I. Intra- and inter-regional exports

$\begin{array}{lcccc} & 1970 & 1980 & 1994 & 2006 \\ \text { North America } & & & & \\ \text { Intra-regional (\%) } & 36 & 34 & 49 & 54 \\ \text { Western Europe (\%) } & 26 & 24 & 16 & 14 \\ \text { Asia (\%) } & 17 & 18 & 24 & 18 \\ \text { Latin America (\%) } & 3 & 2 & 3 & 2 \\ \text { Western Europe } & & & & \\ \text { Intra-regional (\%) } & 51 & 60 & 60 & 59 \\ \text { North America (\%) } & 10 & 7 & 9 & 18 \\ \text { Asia (\%) } & 6 & 4 & 9 & 8 \\ \text { Latin America (\%) } & 1 & 1 & 1 & 1 \\ \text { Asia } & & & & \\ \text { Intra-regional (\%) } & 34 & 34 & 48 & 52 \\ \text { North America (\%) } & 29 & 15 & 25 & 14 \\ \text { Western Europe (\%) } & 11 & 1 & 15 & 1 \\ \text { Latin America (\%) } & 1 & & & \\ \text { Latin America } & & 17 & 20 & 15 \\ \text { Intra-regional (\%) } & 11 & 18 & 20 & 21 \\ \text { North America (\%) } & 19 & 39 & 27 & 18 \\ \text { Western Europe (\%) } & 48 & 11 & 18 & \\ \text { Asia (\%) } & 8 & & & \end{array}$

Table II. Regional flow of FDI

$\begin{array}{llcccc}\text { From } & \text { To } & \text { 1990 (\%) } & \text { 1997 (\%) } & \text { 2000 (\%) } & \text { 2004 (\%) } \\ \text { North America } & \text { North America } & 26 & 33 & 36 & 27 \\ \text { North America } & \text { Western Europe } & 48 & 36 & 42 & 21 \\ \text { North America } & \text { Asia } & 20 & 17 & 16 & 48 \\ \text { North America } & \text { Latin America } & 5 & 14 & 6 & 3 \\ \text { Western Europe } & \text { Western Europe } & 59 & 39 & 61 & 72 \\ \text { Western Europe } & \text { North America } & 32 & 37 & 31 & 15 \\ \text { Western Europe } & \text { Asia } & 8 & 16 & 3 & 7 \\ \text { Western Europe } & \text { Latin America } & 1 & 8 & 4 & 5 \\ \text { Asia } & \text { North America } & 39 & 75 & 63 & 63 \\ \text { Asia } & \text { Asia } & 43 & 18 & 18 & 22 \\ \text { Asia } & \text { Western Europe } & 18 & 6 & 19 & 15 \\ \text { Asia } & \text { Latin America } & 1 & 1 & 0 & 0 \\ \text { Latin America } & \text { Latin America } & 8 & 72 & 30 & 6 \\ \text { Latin America } & \text { North America } & 27 & 5 & 43 & 77 \\ \text { Latin America } & \text { Western Europe } & 66 & 23 & 26 & 15 \\ \text { Latin America } & \text { Asia } & 0 & 0 & 2 & 2\end{array}$

Multinational Business Review, Vol 19, No. 1 (2011): pg. 26-35. DOI. This article is (C Emerald and permission has been granted for this version to appear in e-Publications@Marquette. Emerald does not grant permission for this article to be further copied/distributed or hosted elsewhere without the express permission from Emerald. 